\title{
A Study on the Evolution Characteristics and Key Drivers of Urban Entrepreneurial Ecosystem: From the Perspective of Complexity Science
}

\author{
Peng Xiong*, Lingli Qing \\ Graduate School of Management of Technology, Pukyong National University, Busan, Korea \\ Email address: \\ 11675512@qq.com (Peng Xiong), 104869242@qq.com (Lingli Qing) \\ ${ }^{*}$ Corresponding author \\ To cite this article: \\ Peng Xiong, Lingli Qing. A Study on the Evolution Characteristics and Key Drivers of Urban Entrepreneurial Ecosystem: From the Perspective \\ of Complexity Science. International Journal of Economic Behavior and Organization. Vol. 9, No. 3, 2021, pp. 109-120. \\ doi: $10.11648 /$ j.ijebo.20210903.19
}

Received: August 27, 2021; Accepted: September 8, 2021; Published: September 23, 2021

\begin{abstract}
Entrepreneurial activity is a typical complex social system with significant regional heterogeneity. Most of the existing studies focus on explaining a certain aspect of entrepreneurial activities or exploring the extent to which regional entrepreneurial activities promote regional economic growth. However, examining regional entrepreneurial activities from a systematic rather than fragmented perspective may be able to reflect their internal and external quality more comprehensively and accurately. The purpose of this paper is to study the key factors affecting the quality of entrepreneurial activities in large Chinese cities based on the theories of "Entrepreneurial Ecosystem" and "Complexity System", and put forward corresponding recommendation on policy design and policy implementation. Based on a systematic review of studies on city-level entrepreneurial ecosystems and the application of complexity science in entrepreneurial research, The Urban Entrepreneurship Ecosystem Index (UEEI) system is constructed, which consists of three dimensions of synergy, emergence and phase change, 10 first-level indicators and 40 second-level indicators. The cross-section data of 2018 are used to make quantitative analysis on China's top ten quasi-first-tier cities such as Wuhan and Chengdu. The results show that the urban entrepreneurial ecosystem is characterized by coordination, emergence and phase transformation, and the more balanced the three characteristics are, the higher the quality of the urban entrepreneurial ecosystem will be. In terms of specific indicators, employment, technological innovation and education are the key order parameters, and the performance of a key order parameter is particularly excellent, which is a common characteristic of high-quality urban entrepreneurial ecosystem.
\end{abstract}

Keywords: Entrepreneurial Activity, Entrepreneurial Ecosystem, Complexity Science

\section{Introduction}

The research on the role of entrepreneurship in promoting economic growth can be traced back to the Schumpeter period. Due to the significant heterogeneity of entrepreneurial activities, the role of entrepreneurship in promoting regional economic growth is also significantly different. Entrepreneurial activities are both the cause of economic growth and the result of economic growth. The two-way causality makes research on the evaluation of the quality of entrepreneurial activities and its role in promoting the economy still in the stage of contention.

Scholars have reached a preliminary consensus. Due to the differences in production efficiency and innovation ability among regions, not all types of entrepreneurial activities can promote economic growth to the same extent under different institutional backgrounds. The same entrepreneurial activities have obvious and different marginal utility in different geographical regions. It is still a challenging task to explain how various factors promote regional economic growth through complex interactions and to what extent $[1,2]$.

The concept of "entrepreneurial ecosystem" that has emerged in recent years provides a biological metaphor for entrepreneurial activities, which vividly reflects the root of the complexity of entrepreneurial activities---non-linearity, that is, the mutual influence and interaction between various 
entities in entrepreneurial activities, showing a non-linear relationship, the external input and system output do not conform to the superposition principle. As a holistic research method, the evaluation of the operating status of the entrepreneurial ecosystem in a specific area can objectively reflect the quality of entrepreneurial activities in this regional environment, and it can also directly reflect the impact of entrepreneurial activities on regional economic growth.

Based on the definition of geographic boundaries of urban, regional and national entrepreneurial ecosystems, this paper focuses on the measurement of urban entrepreneurial ecosystems in the Chinese context. The Urban Entrepreneurship Ecosystem Index (UEEI) is constructed to measure the quality of urban entrepreneurial activities in the Chinese context. The rationality and practicability of the index system are verified through the evaluation and analysis of panel data of 10 provincial capitals with rapid development and good economic foundation in different regions of China. The analysis results have some enlightenment for policy makers and entrepreneurs.

\section{Literature Review}

\subsection{A Review of Research on Urban Entrepreneurial Ecosystems}

As early as 1982, Pennings pointed out that the behaviors of entrepreneurs could not be explained only by rational economic models. When choosing different cities as business locations, they would consider not only the local economic conditions, but also many non-economic conditions. The integration of economic and non-economic indicators provides a multi-dimensional perspective for the study of entrepreneurial activities, which can explain the entrepreneurial ability of a city more objectively and truly. Since then, scholars have followed this multi-dimensional research concept and conducted research on the urban entrepreneurial ecosystem from both internal and external aspects.

Research on the internal aspects of the urban entrepreneurial ecosystem mainly focuses on the factors affecting entrepreneurial activities, and the representative research results are shown in Table 1.

Table 1. Influencing factors of urban entrepreneurial activities.

\begin{tabular}{|c|c|c|}
\hline NO. & Proposer & Influencing factors/measurement variables \\
\hline 1 & $\begin{array}{l}\text { Erik Stam } \\
\text { Andrew van } \\
\text { de Ven (2019) } \\
{[3]}\end{array}$ & $\begin{array}{l}\text { 1) Quality of government governance: corruption, rule of law, government effectiveness and accountability; 2) New companies: } \\
\text { Percentage of new companies registered per thousand people; 3) Accessibility: Number of roads, railways and airports; 4) } \\
\text { Demand: average purchasing power, regional products, total population; 5) Innovation cooperation: Proportion of enterprises } \\
\text { carrying out innovation cooperation; 6) Leadership: Number of innovation program leaders per } 1,000 \text { companies; 7) Education: } \\
\text { Percentage of adults with higher education; 8) Venture capital: Amount of venture capital per } 1000 \text { companies; 9) R\&D: } \\
\text { Percentage of GDP; 10) Business services: percentage of service-oriented companies in the business population. }\end{array}$ \\
\hline 2 & $\begin{array}{l}\text { X. Q. Xie, J. J. } \\
\text { Huang (2017) } \\
{[4]}\end{array}$ & $\begin{array}{l}\text { 1) Pressure: resident population, city's fiscal revenue, total investment in fixed assets, consumer price index, annual per capita } \\
\text { disposable income of urban residents, annual per capita consumption expenditure of urban residents; 2) Status: total number of } \\
\text { high-tech enterprises, total output value of high-tech industries, patent authorizations, registered scientific and technological } \\
\text { achievements, technical contract transactions, loans from financial institutions; 3) Response: R\&D expenditure, education } \\
\text { expenditure, science and technology expenditure, social security and employment expenditure, public service expenditure, aviation } \\
\text { civil airlines, road mileage, Internet broadband and fiber optic users. }\end{array}$ \\
\hline 3 & Wei (2018) [5] & $\begin{array}{l}\text { 1) Pressure: resident population, city's per capita fiscal revenue, city's per capita total investment in fixed assets, consumer price } \\
\text { index, urban residents' annual per capita disposable income, urban residents' annual per capita consumption expenditure; } 2 \text { ) Status: } \\
\text { Total number of high-tech enterprises per million people, patent grants per million people, registered scientific and technological } \\
\text { achievements per million people, per capita technology market turnover, loans from per capita financial institutions; } 3 \text { ) Response: } \\
\text { R\&D expenditure per capita, education expenditure per capita, science and technology expenditure per capita, social security and } \\
\text { employment expenditure per capita, public service expenditure per capita, highway mileage per } 10,000 \text { square kilometers, Internet } \\
\text { broadband access users per } 10,000 \text { people. }\end{array}$ \\
\hline 4 & $\begin{array}{l}\text { Martin } \\
\text { Hemmert et al. } \\
(2019)[6]\end{array}$ & $\begin{array}{l}\text { 1) Agglomeration size: population, GDP, number of enterprises; 2) Entrepreneurship ecological attributes: number of newly } \\
\text { established companies, number of unicorns, type of industry, growth rate; 3) Entrepreneurial attributes: average age, percentage of } \\
\text { female entrepreneurs, percentage of immigrant entrepreneurs, percentage of multiple entrepreneurs. }\end{array}$ \\
\hline 5 & $\begin{array}{l}\text { David B. } \\
\text { Audretsch } \\
\text { Maksim } \\
\text { Belitski } \\
(2016)[7]\end{array}$ & $\begin{array}{l}\text { 1) New Enterprises: New Enterprises Percentage in City; 2) Culture and norms: sense of safety in the city where you are located, } \\
\text { sense of safety in the surrounding cities, percentage of trustworthy people around; 3) Infrastructure: Satisfaction with accessibility, } \\
\text { satisfaction with urban greenery, satisfaction with urban tidiness, satisfaction with cultural facilities; 4) Internet Convenience: } \\
\text { Satisfaction with Internet Services; 5) Formal system: percentage of people who think the government is responsible, percentage of } \\
\text { people who think administrative agencies are helpful for entrepreneurial activities; 6) Inclusivity: foreigners comfortable } \\
\text { integration proportion; 7) Demand: proportion of housing demand, proportion of finding a good job; 8) GDP: GDP by PPP. }\end{array}$ \\
\hline 6 & $\begin{array}{l}\text { EU REDI } \\
(2013)[8]\end{array}$ & $\begin{array}{l}\text { 1) Entrepreneurial attitude: cultural support, networking, risk acceptance, entrepreneurial skills, opportunity perception; 2) } \\
\text { Entrepreneurial skills: collaboration, human resources, technology applications, opportunity-based entrepreneurship; 3) } \\
\text { Entrepreneurship desire: convenience of financing, degree of globalization, high growth, process innovation ability, product } \\
\text { innovation ability. }\end{array}$ \\
\hline
\end{tabular}

In addition, scholars have also done a lot of research work on the participants in the urban entrepreneurial ecosystem and the relationship between them. In urban entrepreneurial activity, the efforts of individual entrepreneurs and the external environment are equally important, and the creation of a regional environment conducive to entrepreneurship and economic development determines the character of a city [9]. In different cities of the same country, the average annual number of start-ups varies greatly. The more developed the economy, the more the average annual increase of start-ups, the higher the proportion of opportunity entrepreneurship and the higher the proportion of local entrepreneurship [10]. 
Entrepreneurial behavior is strongly influenced by the urban environment in which they are located and has a direct positive or negative effect on their entrepreneurial attitudes, aspirations and opportunities; in addition, the local environment can determine whether the type of startup is more demand-driven or opportunity-driven, and has a significant impact on their growth rate. At the cultural level, the influence of successful entrepreneurs on potential entrepreneurs is significant, and the power of their words, actions and role models helps potential entrepreneurs learn entrepreneurial knowledge and management experience, and also eliminates potential entrepreneurs' fear and uncertainty to a certain extent [3].

As the two most important participants in the entrepreneurial ecosystem, the relationship between enterprises and the government is particularly complex. Enterprises benefit from both government governance and official corruption, while entrepreneurs' social networks can only make up for some institutional defects. Therefore, the entrepreneurial constraints caused by corruption are still very obvious in some cities [11]. Government regulatory regimes significantly influence the type and growth of entrepreneurial ventures and have a profound impact on regional entrepreneurship [12]. The regional entrepreneurial spirit precipitated in the historical development process has obvious continuity and stability, and its impact on regional entrepreneurial activities will last for decades or even longer [13]. Research on external aspects of urban entrepreneurial ecosystems has focused on the positive and negative externalities affecting regional and urban entrepreneurial activity. Empirical research shows that the knowledge spillover theory of entrepreneurship is also applicable to regions and industries. Universities and large high-tech enterprises have significant knowledge spillover effects on surrounding regions. The number of start-ups in these regions is significantly higher than that in other regions, because knowledge spillover promotes creative individuals to choose to become entrepreneurs, or promote entrepreneurs to recognize new entrepreneurial opportunities and commercialize them. What plays a decisive role in knowledge spillover is the number of universities, the total population and the increased number in cities [14].

\subsection{A review of Complexity Theory Research in Entrepreneurial Activity}

According to the famous Chinese scientist Qian Xuesen's reclassification of systems, the social system has many subsystems, complex relationships between hierarchical structures, and the influence of factors such as human participation, learning and adaptation. It is a typical, special and complex giant system. Although there is far from a consensus among scholars on the definition and research areas of complexity science, in general, complexity science offers a new perspective and a new integrated approach to the study of various disciplines, i.e. it requires scholars to pay more attention to the integrity of the object of study, to the connectedness of the elements that make up the system of the object, and to the non-superimposing incremental nature of the parts that make up the whole.

Entrepreneurship research is a field that has deep roots in complex science. Since Bygrave applied chaos theory to explain entrepreneurship theory in 1989, scholars have re-examined all aspects of entrepreneurial activities from various perspectives of complexity science and have come up with some new understandings. The reason is that the research of entrepreneurial activity and complexity science requires innovation, novelty, and newness [15], and complexity theory and its constituent concepts can provide some meaningful insights into entrepreneurial-related knowledge phenomena, and provide possible explanations for them [16]. Entrepreneurial activity and regional economic development is undoubtedly a complex system with dynamic nature, and the participating subjects within it constitute a network that interacts with each other in a nonlinear manner, and the dynamic equilibrium process of interdependence and mutual influence among the subjects can be better explained by using the theory of co-evolution in complexity science [17]. Whereas the business environment in which the entire entrepreneurial activity takes place is composed of a series of relationships between agents and stakeholders, and this network of relationships can change significantly due to human subjectivity, a key factor in complex systems, most factors in complex systems do not change the overall characteristics of the network of relationships [18], which is in line with the nature of the key sequential covatiates of synergy theory.

As a foundational feature of complexity science and a source of complexity, emergence theory emphasizes the circumstances under which and how a new order emerges, and the creation of new enterprises is undoubtedly one of the manifestations of new order establishment, a classic form of creative destruction [19]. In contrast, the entrepreneurial process of a single firm can be seen as a temporary change in the overall complex system, a process that breaks the original economic equilibrium to a considerable extent, injecting a new economic order into the complex system in the form of technological innovation, organizational and process innovation, business model innovation, etc. [20]. Phase change is the fundamental reason why complex systems are in a non-equilibrium state and refers to the overall, qualitative, macroscopic changes in the system due to quantitative changes in each participating subject or subsystem, i.e. phase change [21]. The phase transition of the system as a whole is sometimes fast and violent, sometimes slow and mild, but at the critical moment when the phase transition is about to be reached there are some parameters that show significant anomalies, and the body (subsystem) that has these parameters will benefit more from the phase transition of the complex system [22, 23]. According to this theory, in a rapidly changing external environment, companies that employ an aggressive and disruptive strategy are more likely to succeed because this strategy is more in line with the overall system characteristics and more likely to capture entrepreneurial opportunities; in a smoothly changing external environment, traditional strategies and formal planning activities are more 
conducive to company success. Therefore, adaptation to the external environment, or the external environment, is crucial for the development of a business, especially a start-up [24, 25].

\section{Construction of an Urban Entrepreneurial Ecology Index Based on a Complex Science Perspective}

In addition to its biological metaphorical meaning, the term "entrepreneurial ecosystem" more importantly reflects the basic characteristics of entrepreneurial activities as a complex system, namely, the large number of participating actors, the complex non-linear interactions among them, and the nested levels of time, space and function. These characteristics also determine the three features of complex systems embodied in the entrepreneurial ecosystem: synergy, emergence and phase change.

Synergy is a fundamental feature of the entrepreneurial ecosystem, and co-evolution is an inevitable response of the system's enterprises and other participating agents in a competitive situation. By cooperating with other firms to complement each other, it can enable both or more parties to achieve better development of themselves at a smaller cost. The theory of synergism suggests that in the evolution of a complex system, a small number of slowly changing sequential covariates instead determine the overall characteristics and evolutionary direction of the system. Accordingly, the parameters related to enterprises, especially startups, in the entrepreneurial ecosystem can be selected as key sequential parameters to reflect the synergistic pattern of the whole entrepreneurial ecosystem, and then judge the overall quality of the system.

Emergence is the source of the complexity of the entrepreneurial ecosystem. The interaction between enterprises, policy makers and various service providers constituting a whole leads to a holistic character that is greater than the simple sum of the subsystems, i.e., the contribution of the entrepreneurial ecosystem as a whole to the regional economy is greater than the simple sum of the single contribution of each enterprise in the system, which is the greatest value of the existence of the entrepreneurial ecosystem. However, it is important to emphasize that emergence is a characteristic unique to the system as a whole and not possessed by individual subsystems. Factors that influence emergence generation include: participating subjects, self-organization, and the external environment. Participating subjects are the necessary conditions for emergence generation, and are the most critical agents of emergence generation, such as workers or entrepreneurs in the entrepreneurial ecosystem are the main participating subjects. The "convergence effect" generated by the self-organizing behavior of the subjects directly leads to the emergence of the emergence, which is the source of power generation of the emergence. This self-organization is not chaotic and disorderly, but has to follow certain rules and restrictions, such as economic and geographical conditions, transportation, hardware facilities, etc. Therefore, this self-organization is restricted generation. In addition, emergence requires the right external environment, both as a system as a whole and as component subsystems, which constantly need to interact with the external environment. The external environment, such as education, municipalities, transportation, etc., provides the energy needed for the evolution of the complex system and imposes significant constraints, thus forcing the complex system to further adapt to the external system, readjusting its internal structure and operating mechanism, and ultimately realizing the "emergence" of the whole over the sum of its parts.

Phase change is a universal characteristic of complex systems, and the prerequisite for its creation is that the system must be able to establish exchange relations with the external environment and be open, so that it can contribute to the internal equilibrium of the system and reach the critical state of phase change. In terms of this theory, the urban entrepreneurial ecosystem is always in a state of dynamic equilibrium, and only when internal and external factors work together to make the system reach a critical state will the overall "phase" of the system change, and this critical moment is often accompanied by some abnormal changes in parameters. The more complex the system is, the slower and more stable the phase change is. According to the entrepreneurial S-curve theory, the entrepreneurial ecosystem will go through three stages: factor-driven, efficiency driven and innovation-driven, and its construction and evolution cannot be achieved overnight, but requires a longer period of time to settle. In this process, the technological innovation results generated by entrepreneurial activities and the indicators related to promoting economic development and improving the living standard of residents can be used as the key parameters of the overall system "phase change".

In summary, based on the perspective of complexity science, the Urban Entrepreneurship Ecosystem Index (UEEI), which consists of 10 primary indicators and 40 secondary indicators, is constructed from three dimensions of synergy, emergence and phase change, as shown in Table 2.

Table 2. City Entrepreneurship Ecological Index Measurement Indicators.

\begin{tabular}{|c|c|c|c|c|c|}
\hline Dimension & Tier 1 indicators & No. & Secondary Indicator & Unit & Number \\
\hline \multirow{7}{*}{ Synergy } & \multirow{5}{*}{ Population } & 1 & Total population & 10,000 people & $\mathrm{C} 01$ \\
\hline & & 2 & Population growth rate & $\%$ & $\mathrm{C} 02$ \\
\hline & & 3 & Number of R\&D staff & People & $\mathrm{C} 03$ \\
\hline & & 4 & Number of cell phone users & 10,000 families & $\mathrm{C} 04$ \\
\hline & & 5 & Number of Internet broadband access subscribers & 10,000 families & $\mathrm{C} 05$ \\
\hline & \multirow{2}{*}{ Enterprise } & 6 & Foreign direct investment contract projects & pcs & $\mathrm{C} 11$ \\
\hline & & 7 & Actual amount of foreign capital used in the year & $10,000 \$$ & $\mathrm{C} 12$ \\
\hline
\end{tabular}




\begin{tabular}{|c|c|c|c|c|c|}
\hline Dimension & Tier 1 indicators & No. & Secondary Indicator & Unit & Number \\
\hline \multirow{18}{*}{ Emerge } & \multirow{6}{*}{ Demand } & 8 & Number of industrial enterprises above the scale & pes & $\mathrm{C} 13$ \\
\hline & & 9 & Total profit of enterprises above the scale & $10,000 ¥$ & $\mathrm{C} 14$ \\
\hline & & 10 & Total retail sales of social consumer goods & $10,000 ¥$ & $\mathrm{C} 21$ \\
\hline & & 11 & Number of wholesale and retail trade enterprises & pes & $\mathrm{C} 22$ \\
\hline & & 12 & Import of goods & $10,000 ¥$ & $\mathrm{C} 23$ \\
\hline & & 13 & Proportion of tertiary industry & $\%$ & $\mathrm{C} 24$ \\
\hline & \multirow{4}{*}{ Education } & 14 & Number of general higher education schools & pcs & $\mathrm{C} 31$ \\
\hline & & 15 & Number of full-time teachers in general higher education institutions & People & $\mathrm{C} 32$ \\
\hline & & 16 & Number of general undergraduate and college students & People & $\mathrm{C} 33$ \\
\hline & & 17 & Education Expenses & $10,000 ¥$ & $\mathrm{C} 34$ \\
\hline & \multirow{4}{*}{ Municipalities } & 18 & Total investment in municipal construction & $10,000 ¥$ & $\mathrm{C} 41$ \\
\hline & & 19 & Sales area of commercial properties & $10,000 \mathrm{sqm}$ & $\mathrm{C} 42$ \\
\hline & & 20 & Local general public budget revenue & $10,000 ¥$ & $\mathrm{C} 43$ \\
\hline & & 21 & Social electricity consumption & million $\mathrm{kWh}$ & $\mathrm{C} 44$ \\
\hline & \multirow{4}{*}{ Transportation } & 22 & Total annual bus passenger traffic & 10,000 people & $\mathrm{C} 51$ \\
\hline & & 23 & Number of actual cabs at the end of the year & Vehicle & $\mathrm{C} 52$ \\
\hline & & 24 & Road, water and air passenger volume & Vehicle & $\mathrm{C} 53$ \\
\hline & & 25 & Road, water and air freight volume & 10,000 ton & $\mathrm{C} 54$ \\
\hline \multirow{15}{*}{$\begin{array}{l}\text { Phase } \\
\text { change }\end{array}$} & \multirow{3}{*}{ Economy } & 26 & Gross regional product (current year prices) & $10,000 ¥$ & C61 \\
\hline & & 27 & GDP per capita & $¥$ & C62 \\
\hline & & 28 & GDP growth rate & $\%$ & C63 \\
\hline & \multirow{4}{*}{$\begin{array}{l}\text { Technology } \\
\text { Innovation }\end{array}$} & 29 & Science and technology expenditures & $10,000 ¥$ & $\mathrm{C} 71$ \\
\hline & & 30 & R\&D internal expenditure & $10,000 ¥$ & $\mathrm{C} 72$ \\
\hline & & 31 & Patent Applications & pes & $\mathrm{C} 73$ \\
\hline & & 32 & Patents granted for inventions & pcs & $\mathrm{C} 74$ \\
\hline & \multirow{5}{*}{ Employment } & 33 & Number of employees in urban units & People & $\mathrm{C} 81$ \\
\hline & & 34 & Number of urban self-employed and private employees & People & $\mathrm{C} 82$ \\
\hline & & 35 & IT industry employment & People & $\mathrm{C} 83$ \\
\hline & & 36 & Registered urban unemployment & People & $\mathrm{C} 84$ \\
\hline & & 37 & Average wage of employees & $¥$ & $\mathrm{C} 85$ \\
\hline & \multirow{3}{*}{ Environment } & 38 & PM2.5 & $\mu \mathrm{g} / \mathrm{m}^{3}$ & C91 \\
\hline & & 39 & Urban construction land area & $\mathrm{sq} \mathrm{km}$ & C92 \\
\hline & & 40 & Greening coverage of built-up areas & $\%$ & C93 \\
\hline
\end{tabular}

\section{Evaluation Analysis}

\subsection{Data Collection}

The quality of entrepreneurial activity in cities has a significant positive correlation with the level of economic development of the city. Considering that the level of economic development varies greatly among provinces (municipalities directly under the central government) and different regions within provinces in China, comparative analysis at the provincial level or among cities with large disparities has limited significance for mutual reference. Based on this consideration, this study selects 10 "quasi-first-tier" provincial capitals, namely Shenyang, Nanjing, Hangzhou, Hefei, Zhengzhou, Wuhan, Changsha, Chengdu, Kunming, and Xi'an, which are recognized by society as being in the middle and upper reaches of the country, according to the economic development level of each provincial capital city in China in recent years. According to the indicators listed in Table 2, the data of the above 10 cities in 2018 were collected from authoritative statistical reports such as China City Statistical Yearbook 2019, China Torch Statistical Yearbook 2019, China Statistical Yearbook 2019, China High Technology Industry Statistical Yearbook 2019 and National Enterprise Innovation Survey Yearbook 2019, as shown in Table 3.

Table 3. Data sheet of 10 cities in 2018.

\begin{tabular}{|c|c|c|c|c|c|c|c|}
\hline No. & Secondary index & Serial number & Shenyang & Nanjing & Hangzhou & Hefei & Zhengzhou \\
\hline 1 & Total population & $\mathrm{C} 01$ & 746 & 697 & 774 & 758 & 864 \\
\hline 2 & Population growth rate & $\mathrm{C} 02$ & -0.52 & 5.34 & 6.91 & 15.43 & 11.7 \\
\hline 3 & Number of R\&D staff & $\mathrm{C} 03$ & 54179 & 129400 & 92897 & 86032 & 78797 \\
\hline 4 & Number of cell phone users & $\mathrm{C} 04$ & 1318 & 1284 & 1801 & 1007 & 1592 \\
\hline 5 & Number of Internet broadband access subscribers & $\mathrm{C} 05$ & 238 & 452 & 509 & 315 & 430 \\
\hline 6 & Foreign direct investment contract projects & $\mathrm{C} 11$ & 162 & 627 & 744 & 140 & 82 \\
\hline 7 & Actual amount of foreign capital used in the year & $\mathrm{C} 12$ & 143097 & 385339 & 682658 & 323000 & 421080 \\
\hline 9 & Total profit of enterprises above the scale & $\mathrm{C} 14$ & 2983000 & 8949600 & 9387351 & 2402497 & 4528100 \\
\hline 10 & Total retail sales of social consumer goods & $\mathrm{C} 21$ & 40512312 & 58324550 & 57153259 & 29767420 & 42680900 \\
\hline 11 & Number of wholesale and retail trade enterprises & $\mathrm{C} 22$ & 1606 & 3085 & 4459 & 1347 & 1935 \\
\hline 12 & Imports of goods & $\mathrm{C} 23$ & 6421482 & 18165160 & 18281654 & 8271521 & 15278657 \\
\hline 13 & Proportion of tertiary industry & $\mathrm{C} 24$ & 58.1 & 61.04 & 63.9 & 50.28 & 54.67 \\
\hline
\end{tabular}




\begin{tabular}{|c|c|c|c|c|c|c|c|}
\hline No. & Secondary index & Serial number & Shenyang & Nanjing & Hangzhou & Hefei & Zhengzhou \\
\hline 14 & Number of general higher education schools & C31 & 47 & 53 & 40 & 50 & 61 \\
\hline 15 & $\begin{array}{l}\text { Number of full-time teachers in general higher education } \\
\text { institutions }\end{array}$ & $\mathrm{C} 32$ & 26564 & 51765 & 30247 & 27073 & 51083 \\
\hline 16 & Number of general undergraduate and college students & $\mathrm{C} 33$ & 391152 & 726728 & 431965 & 497131 & 993479 \\
\hline 17 & Education Expenditure & $\mathrm{C} 34$ & 1152055 & 2530631 & 3154350 & 1635053 & 2129214 \\
\hline 18 & Total investment in municipal construction & $\mathrm{C} 41$ & 3016000 & 1346168 & 4752369 & 1685889 & 5032424 \\
\hline 19 & Sales area of commercial properties & $\mathrm{C} 42$ & 1355 & 1221 & 1676 & 1390 & 3712 \\
\hline 20 & Local general public budget revenue & $\mathrm{C} 43$ & 7206425 & 14700152 & 18250616 & 7124862 & 11520568 \\
\hline 21 & Social electricity consumption & $\mathrm{C} 44$ & 3574457 & 6064005 & 7969558 & 3448296 & 5603221 \\
\hline 22 & Total annual bus passenger traffic & C51 & 110200 & 88750 & 153729 & 55449 & 94000 \\
\hline 23 & Number of actual cabs at the end of the year & C52 & 17544 & 13354 & 13714 & 9402 & 10908 \\
\hline 24 & Road, water and air passenger volume & $\mathrm{C} 53$ & 15163 & 9551 & 11983 & 8041 & 9049 \\
\hline 25 & Road, water and air freight volume & C54 & 82939 & 91347 & 671489 & 34143 & 340779 \\
\hline 26 & Gross regional product (current year prices) & $\mathrm{C} 61$ & 62923981 & 128204000 & 135091508 & 78229061 & 101433173 \\
\hline 27 & GDP per capita & $\mathrm{C} 62$ & 75766 & 152886 & 140180 & 97470 & 101349 \\
\hline 28 & GDP growth rate & $\mathrm{C} 63$ & 5.41 & 8.0 & 6.72 & 8.54 & 8.3 \\
\hline 29 & Science and technology expenditures & $\mathrm{C} 71$ & 181126 & 805440 & 1182090 & 919741 & 361748 \\
\hline 30 & R\&DInternal expenditure & $\mathrm{C} 72$ & 1687755 & 4165800 & 4643000 & 2566521 & 1852996 \\
\hline 31 & R\&D internal expenditure & $\mathrm{C} 73$ & 23826 & 99020 & 98396 & 65814 & 70128 \\
\hline 32 & Patent Applications & $\mathrm{C} 74$ & 2943 & 11090 & 10267 & 5597 & 10654 \\
\hline 33 & Patents granted for inventions & $\mathrm{C} 81$ & 1182341 & 2191563 & 2791875 & 1832891 & 1879346 \\
\hline 34 & Number of employees in urban units & $\mathrm{C} 82$ & 1988990 & 4852270 & 4380227 & 1462900 & 2085738 \\
\hline 35 & Number of urban self-employed and private employees & $\mathrm{C} 83$ & 23905 & 186841 & 160400 & 48843 & 52964 \\
\hline 36 & IT industry employment & $\mathrm{C} 84$ & 96465 & 61821 & 42706 & 109453 & 68277 \\
\hline 37 & Registered urban unemployment & $\mathrm{C} 85$ & 82067 & 111071 & 106709 & 89022 & 80963 \\
\hline 38 & Average wage of employees & C91 & 46 & 43 & 32 & 49 & 63 \\
\hline 39 & PM2.5 & $\mathrm{C} 92$ & 630 & 774 & 571 & 457 & 529 \\
\hline 40 & Urban construction land area & $\mathrm{C} 93$ & 39.23 & 45.1 & 40.63 & 43.37 & 40.83 \\
\hline
\end{tabular}

Table 3. Continued.

\begin{tabular}{|c|c|c|c|c|c|c|c|}
\hline No. & Secondary index & Serial number & Wuhan & Changsha & Chengdu & Kunming & Xi'an \\
\hline 1 & Total population & $\mathrm{C} 01$ & 884 & 729 & 1476 & 572 & 987 \\
\hline 2 & Population growth rate & $\mathrm{C} 02$ & 8.09 & 7.52 & 3.64 & 8.88 & 10.98 \\
\hline 3 & Number of R\&D staff & $\mathrm{C} 03$ & 86000 & 96345 & 143289 & 65778 & 101500 \\
\hline 4 & Number of cell phone users & $\mathrm{C} 04$ & 1684 & 1251 & 2867 & 1229 & 1858 \\
\hline 5 & Number of Internet broadband access subscribers & $\mathrm{C} 05$ & 493 & 328 & 679 & 249 & 393 \\
\hline 6 & Foreign direct investment contract projects & $\mathrm{C} 11$ & 250 & 329 & 494 & 111 & 219 \\
\hline 7 & Actual amount of foreign capital used in the year & $\mathrm{C} 12$ & 1092684 & 77997 & 1227500 & 85013 & 635370 \\
\hline 8 & Number of industrial enterprises above the scale & $\mathrm{C} 13$ & 2651 & 2934 & 3438 & 1015 & 1385 \\
\hline 9 & Total profit of enterprises above the scale & $\mathrm{C} 14$ & 7334000 & 7939200 & 5200081 & 1498546 & 3455000 \\
\hline 10 & Total retail sales of social consumer goods & $\mathrm{C} 21$ & 68439017 & 47650415 & 68018100 & 27874053 & 46587164 \\
\hline 11 & Number of wholesale and retail trade enterprises & $\mathrm{C} 22$ & 2249 & 2085 & 1599 & 813 & 1292 \\
\hline 12 & Imports of goods & $\mathrm{C} 23$ & 8732000 & 4601922 & 22362832 & 6169230 & 13460734 \\
\hline 13 & Proportion of tertiary industry & $\mathrm{C} 24$ & 54.61 & 54.75 & 54.12 & 56.59 & 61.86 \\
\hline 14 & Number of general higher education schools & $\mathrm{C} 31$ & 84 & 51 & 57 & 51 & 63 \\
\hline 15 & $\begin{array}{l}\text { Number of full-time teachers in general higher education } \\
\text { institutions }\end{array}$ & $\mathrm{C} 32$ & 58586 & 35441 & 49448 & 29496 & 49018 \\
\hline 16 & Number of general undergraduate and college students & $\mathrm{C} 33$ & 969323 & 703519 & 840297 & 547277 & 712810 \\
\hline 17 & Education Expenditure & $\mathrm{C} 34$ & 2599758 & 1946010 & 2658194 & 1300493 & 1571932 \\
\hline 18 & Total investment in municipal construction & $\mathrm{C} 41$ & 11060046 & 661678 & 9206995 & 2155557 & 7730000 \\
\hline 19 & Sales area of commercial properties & $\mathrm{C} 42$ & 2184 & 2387 & 3682 & 1910 & 2713 \\
\hline 20 & Local general public budget revenue & $\mathrm{C} 43$ & 15286984 & 8797072 & 14241550 & 5956333 & 6847035 \\
\hline 21 & Social electricity consumption & C44 & 5803372 & 3636932 & 6374116 & 3374433 & 3967465 \\
\hline 22 & Total annual bus passenger traffic & $\mathrm{C} 51$ & 145246 & 68457 & 161946 & 77240 & 135919 \\
\hline 23 & Number of actual cabs at the end of the year & $\mathrm{C} 52$ & 17885 & 7840 & 14964 & 8037 & 14212 \\
\hline 24 & Road, water and air passenger volume & $\mathrm{C} 53$ & 10419 & 7085 & 14729 & 9155 & 20020 \\
\hline 25 & Road, water and air freight volume & C54 & 237108 & 121197 & 693207 & 458960 & 338330 \\
\hline 26 & Gross regional product (current year prices) & C61 & 148472900 & 110034116 & 153427716 & 52068979 & 83498600 \\
\hline 27 & GDP per capita & C62 & 135136 & 136920 & 94782 & 76387 & 85114 \\
\hline 28 & GDP growth rate & C63 & 8.09 & 8.52 & 8.0 & 8.4 & 8.2 \\
\hline 29 & Science and technology expenditures & $\mathrm{C} 71$ & 1344072 & 361871 & 730705 & 180075 & 482295 \\
\hline 30 & R\&DInternal expenditure & $\mathrm{C} 72$ & 3784174 & 2658635 & 3923101 & 1123800 & 4261400 \\
\hline 31 & $R \& D$ internal expenditure & $\mathrm{C} 73$ & 60511 & 41034 & 107801 & 23921 & 56408 \\
\hline 32 & Patent Applications & $\mathrm{C} 74$ & 8807 & 4823 & 8304 & 1807 & 8023 \\
\hline 33 & Patents granted for inventions & $\mathrm{C} 81$ & 2097735 & 1194467 & 6135401 & 1336684 & 1962340 \\
\hline 34 & Number of employees in urban units & $\mathrm{C} 82$ & 2461100 & 2347700 & 3054922 & 2296869 & 2020051 \\
\hline
\end{tabular}




\begin{tabular}{|c|c|c|c|c|c|c|c|}
\hline No. & Secondary index & Serial number & Wuhan & Changsha & Chengdu & Kunming & Xi'an \\
\hline 35 & Number of urban self-employed and private employees & $\mathrm{C} 83$ & 95381 & 22319 & 331444 & 25305 & 101678 \\
\hline 36 & IT industry employment & C84 & 81900 & 36877 & 204718 & 62380 & 124803 \\
\hline 37 & Registered urban unemployment & $\mathrm{C} 85$ & 88327 & 93293 & 88011 & 80253 & 87125 \\
\hline 38 & Average wage of employees & C91 & 49 & 48 & 51 & 28 & 61 \\
\hline 39 & PM2.5 & C92 & 865 & 505 & 848 & 454 & 658 \\
\hline 40 & Urban construction land area & $\mathrm{C} 93$ & 39.46 & 41.49 & 41.33 & 41.93 & 38.75 \\
\hline
\end{tabular}

\subsection{Data Processing}

The above data was handled using SPSS 20.0 software in the following steps.

Step 1: Transposition of data. Transpose Table 3 with rows and columns of data for the purpose of data analysis.

Step 2: Positiveization of the inverse indicator. PM2.5, the 38th indicator out of the above 40 indicators, is the inverse indicator, and it is made explicit by finding the inverse.
Step 3: Normalization of data. Normalization of the data processed in step 1 to get a table of standardized values.

Step 4: Using the standard values obtained in step 3, the objective weight values determined by the CRITIC method, the entropy weight method and the information quantity method are calculated for each indicator, and the average value determined by the three objective methods is used as the comprehensive objective weight of each indicator, as shown in Table 4.

Table 4. Indicator weight table.

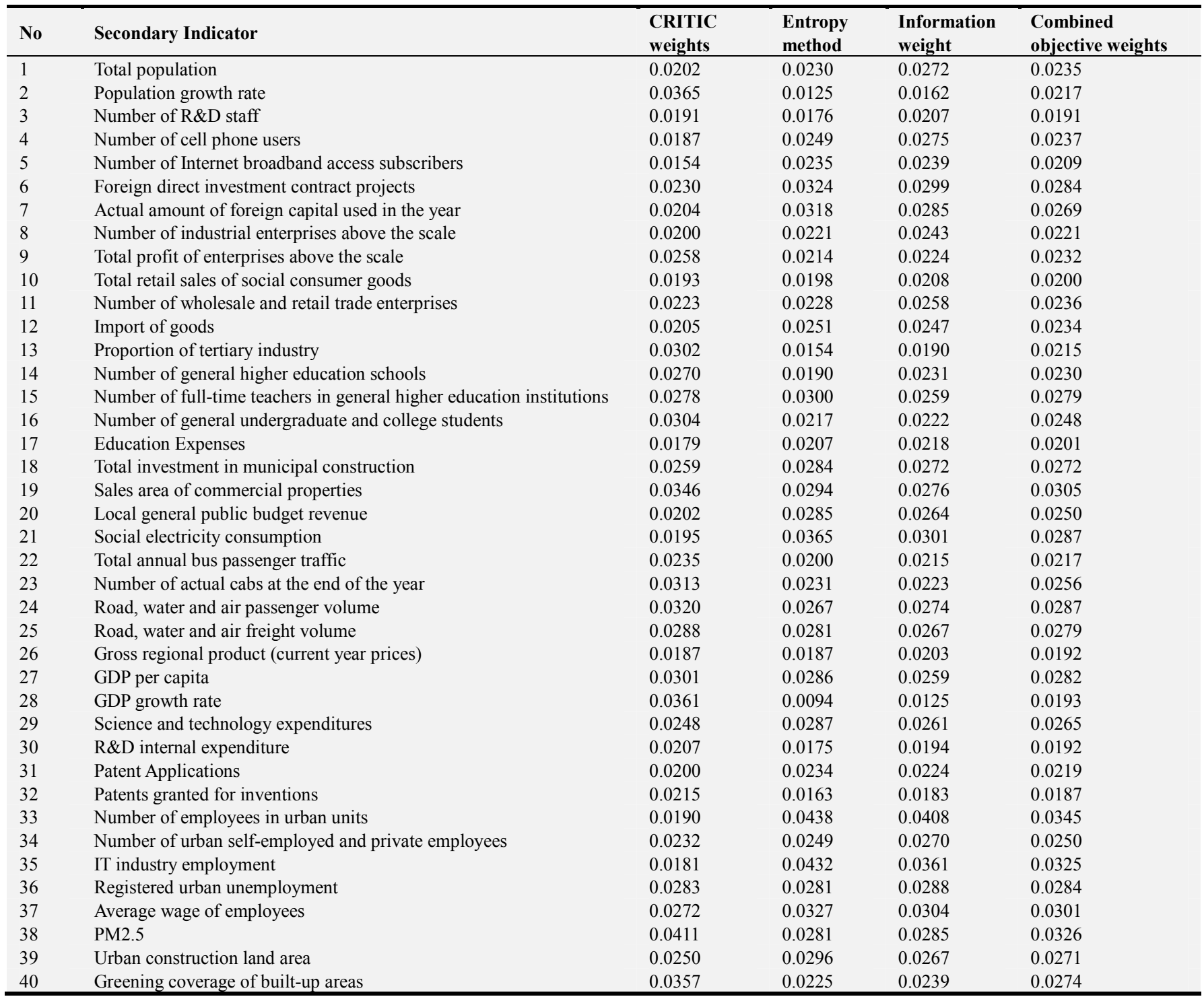

Step 5: Based on the weights of each indicator calculated in step 4 and the standard values obtained in step 3 , the total score of the urban entrepreneurial ecosystem is calculated

with (1). 


$$
C_{\mathrm{i}}=\sum_{j=1}^{n} \mathrm{w}_{i j} \times \mathrm{d}_{i j}, i=1,2 \ldots, 10
$$

In (1), $C_{i}$ is the composite score of entrepreneurial activity of the ith city, $W_{i j}$ is the weight value of the ith city and the jth indicator, and $d_{i j}$ is the standardized value of the ith city and the jth indicator. The scores of each city on the secondary indicators calculated by (1) are shown in Table 5.

Table 5. Score of secondary indicators by city.

\begin{tabular}{|c|c|c|c|c|c|c|c|}
\hline Dimension & $\begin{array}{l}\text { Tier } 1 \\
\text { Indicators }\end{array}$ & Secondary indicators & Shenyang & Nanjing & Hangzhou & Hefei & Zhegnzhou \\
\hline \multirow{13}{*}{ Synergy } & \multirow{5}{*}{ Population } & Total population & 0.0045 & 0.0032 & 0.0052 & 0.0048 & 0.0076 \\
\hline & & Natural growth rate & 0.0000 & 0.0080 & 0.0101 & 0.0217 & 0.0167 \\
\hline & & Number of R\&D staff & 0.0000 & 0.0162 & 0.0083 & 0.0068 & 0.0053 \\
\hline & & Number of cell phone users & 0.0040 & 0.0035 & 0.0101 & 0.0000 & 0.0075 \\
\hline & & Number of Internet broadband access subscribers & 0.0000 & 0.0102 & 0.0129 & 0.0037 & 0.0091 \\
\hline & \multirow{4}{*}{ Enterprise } & Foreign direct investment contract projects & 0.0034 & 0.0234 & 0.0284 & 0.0025 & 0.0000 \\
\hline & & Actual amount of foreign capital used in the year & 0.0015 & 0.0072 & 0.0141 & 0.0057 & 0.0080 \\
\hline & & Number of industrial enterprises above the scale & 0.0022 & 0.0077 & 0.0221 & 0.0064 & 0.0084 \\
\hline & & Total profit of enterprises above the scale & 0.0044 & 0.0219 & 0.0232 & 0.0027 & 0.0089 \\
\hline & \multirow{4}{*}{ Demand } & Total retail sales of social consumer goods & 0.0062 & 0.0150 & 0.0144 & 0.0009 & 0.0073 \\
\hline & & Number of wholesale and retail trade enterprises & 0.0051 & 0.0147 & 0.0236 & 0.0035 & 0.0073 \\
\hline & & Imports of goods & 0.0024 & 0.0179 & 0.0180 & 0.0048 & 0.0141 \\
\hline & & The proportion of tertiary industry & 0.0124 & 0.0170 & 0.0215 & 0.0000 & 0.0069 \\
\hline \multirow{12}{*}{ Emerge } & \multirow{4}{*}{ Education } & Number of general higher education schools & 0.0037 & 0.0068 & 0.0000 & 0.0052 & 0.0110 \\
\hline & & $\begin{array}{l}\text { Number of full-time teachers in general higher education } \\
\text { institutions }\end{array}$ & 0.0000 & 0.0220 & 0.0032 & 0.0004 & 0.0214 \\
\hline & & Number of general undergraduate and college students & 0.0000 & 0.0138 & 0.0017 & 0.0044 & 0.0248 \\
\hline & & Education Expenses & 0.0000 & 0.0139 & 0.0201 & 0.0049 & 0.0098 \\
\hline & \multirow{4}{*}{ Municipalities } & Total investment in municipal construction & 0.0062 & 0.0018 & 0.0107 & 0.0027 & 0.0114 \\
\hline & & Sales area of commercial properties & 0.0016 & 0.0000 & 0.0056 & 0.0021 & 0.0305 \\
\hline & & Local general public budget revenue & 0.0025 & 0.0178 & 0.0250 & 0.0024 & 0.0113 \\
\hline & & Social electricity consumption & 0.0012 & 0.0168 & 0.0287 & 0.0005 & 0.0139 \\
\hline & \multirow{4}{*}{ Traffic } & Total annual bus passenger traffic & 0.0111 & 0.0068 & 0.0200 & 0.0000 & 0.0078 \\
\hline & & Number of actual cabs at the end of the year & 0.0247 & 0.0140 & 0.0150 & 0.0040 & 0.0078 \\
\hline & & Passenger volumes by road, water and air & 0.0179 & 0.0055 & 0.0109 & 0.0021 & 0.0044 \\
\hline & & Fright volumes by road, water and air & 0.0021 & 0.0024 & 0.0269 & 0.0000 & 0.0130 \\
\hline \multirow{15}{*}{ Phase change } & \multirow{3}{*}{ Economy } & Gross regional product (current year prices) & 0.0021 & 0.0144 & 0.0158 & 0.0050 & 0.0094 \\
\hline & & GDP per capita & 0.0000 & 0.0282 & 0.0236 & 0.0079 & 0.0094 \\
\hline & & GDP growth rate & 0.0000 & 0.0160 & 0.0081 & 0.0193 & 0.0179 \\
\hline & \multirow{4}{*}{$\begin{array}{l}\text { Technology } \\
\text { Innovation }\end{array}$} & Science and technology expenditures & 0.0000 & 0.0143 & 0.0228 & 0.0169 & 0.0041 \\
\hline & & $\mathrm{R} \& \mathrm{D}$ internal expenditure & 0.0000 & 0.0166 & 0.0192 & 0.0079 & 0.0040 \\
\hline & & Patent Applications & 0.0000 & 0.0196 & 0.0195 & 0.0110 & 0.0121 \\
\hline & & Number of Invention Patents Granted & 0.0023 & 0.0187 & 0.0170 & 0.0076 & 0.0178 \\
\hline & \multirow{5}{*}{ Employment } & Number of employees in urban units & 0.0000 & 0.0070 & 0.0112 & 0.0045 & 0.0049 \\
\hline & & Number of urban self-employed and private employees & 0.0039 & 0.0250 & 0.0215 & 0.0000 & 0.0046 \\
\hline & & IT industry employment & 0.0002 & 0.0173 & 0.0145 & 0.0028 & 0.0032 \\
\hline & & Registered Urban Unemployment & 0.0101 & 0.0042 & 0.0010 & 0.0123 & 0.0053 \\
\hline & & Average wage of employees & 0.0018 & 0.0301 & 0.0258 & 0.0086 & 0.0007 \\
\hline & \multirow{3}{*}{ Environment } & PM2.5 & 0.0096 & 0.0121 & 0.0252 & 0.0074 & 0.0000 \\
\hline & & Urban construction land area & 0.0116 & 0.0211 & 0.0077 & 0.0002 & 0.0049 \\
\hline & & Greening coverage of built-up areas & 0.0021 & 0.0274 & 0.0081 & 0.0199 & 0.0090 \\
\hline
\end{tabular}

Table 5. Continued.

\begin{tabular}{|c|c|c|c|c|c|c|c|}
\hline Dimension & Tier 1 Indicators & Secondary indicators & Wuhan & Changsha & Chengdu & Kunming & Xi'an \\
\hline \multirow{12}{*}{ Synergy } & \multirow{5}{*}{ Population } & Total population & 0.0081 & 0.0041 & 0.0235 & 0.0000 & 0.0108 \\
\hline & & Natural growth rate & 0.0117 & 0.0110 & 0.0057 & 0.0128 & 0.0157 \\
\hline & & Number of R\&D staff & 0.0068 & 0.0091 & 0.0191 & 0.0025 & 0.0102 \\
\hline & & Number of cell phone users & 0.0086 & 0.0031 & 0.0237 & 0.0028 & 0.0108 \\
\hline & & Number of Internet broadband access subscribers & 0.0121 & 0.0043 & 0.0209 & 0.0005 & 0.0074 \\
\hline & \multirow{3}{*}{ Enterprise } & Foreign direct investment contract projects & 0.0072 & 0.0106 & 0.0177 & 0.0012 & 0.0059 \\
\hline & & Actual amount of foreign capital used in the year & 0.0237 & 0.0000 & 0.0269 & 0.0002 & 0.0130 \\
\hline & & Total profit of enterprises above the scale & 0.0172 & 0.0189 & 0.0109 & 0.0000 & 0.0058 \\
\hline & \multirow{4}{*}{ Demand } & Total retail sales of social consumer goods & 0.0200 & 0.0097 & 0.0198 & 0.0000 & 0.0092 \\
\hline & & Number of wholesale and retail trade enterprises & 0.0093 & 0.0082 & 0.0051 & 0.0000 & 0.0031 \\
\hline & & Imports of goods & 0.0054 & 0.0000 & 0.0234 & 0.0021 & 0.0117 \\
\hline & & The proportion of tertiary industry & 0.0068 & 0.0071 & 0.0061 & 0.0100 & 0.0183 \\
\hline Emerge & Education & Number of general higher education schools & 0.0230 & 0.0058 & 0.0089 & 0.0058 & 0.0120 \\
\hline
\end{tabular}




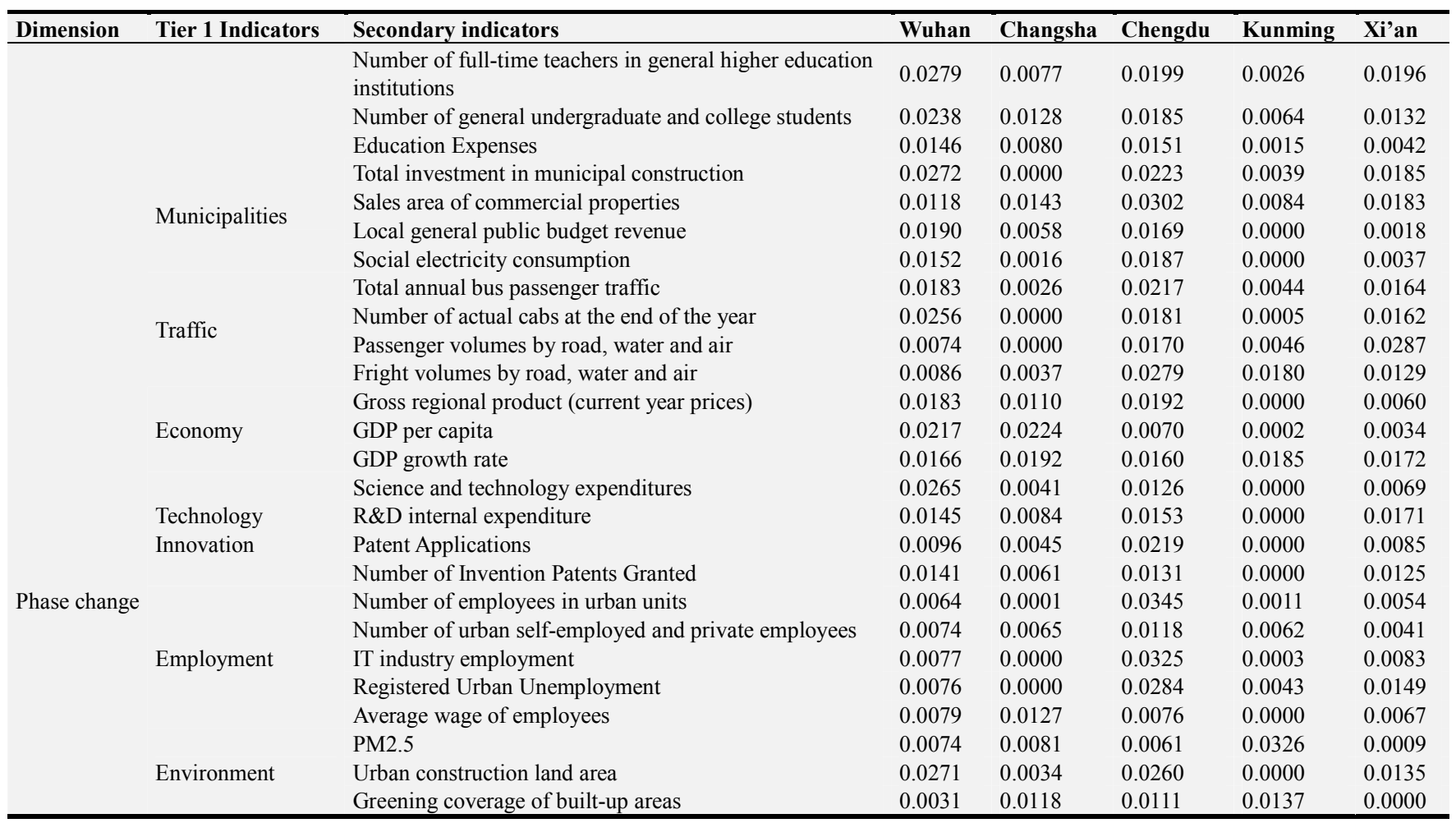

The scores and total score of each city on the three major dimensions are shown in Table 6.

Table 6. Score of each dimension and total score.

\begin{tabular}{|c|c|c|c|c|c|c|c|c|c|c|}
\hline Dimension & Shenyang & Nanjing & Hangzhou & Hefei & Zhengzhou & Wuhan & Changsha & Chengdu & Kunming & Xi'an \\
\hline Collaboration & 0.0462 & 0.1659 & 0.2122 & 0.0635 & 0.1070 & 0.1453 & 0.0957 & 0.2149 & 0.0322 & 0.1237 \\
\hline Emerge & 0.0711 & 0.1215 & 0.1678 & 0.0286 & 0.1671 & 0.2222 & 0.0624 & 0.2352 & 0.0561 & 0.1655 \\
\hline Phase-change & 0.0437 & 0.2721 & 0.2411 & 0.1313 & 0.1072 & 0.1958 & 0.1183 & 0.2630 & 0.0769 & 0.1255 \\
\hline Total score & 0.1610 & 0.5595 & 0.6211 & 0.2234 & 0.3813 & 0.5633 & 0.2764 & 0.7131 & 0.1652 & 0.4146 \\
\hline
\end{tabular}

\subsection{Analysis Results}

The scores of the 10 quasi-first-tier cities on each dimension and total score are shown in Figure 1. In terms of total score, Chengdu, Hangzhou, Wuhan and Nanjing are in the top 4, with relatively few gaps, and are in the first tier; Xi'an, Zhengzhou and Changsha are in the second tier at 5-7; while Hefei, Kunming and Shenyang have lower scores and are in the third tier.

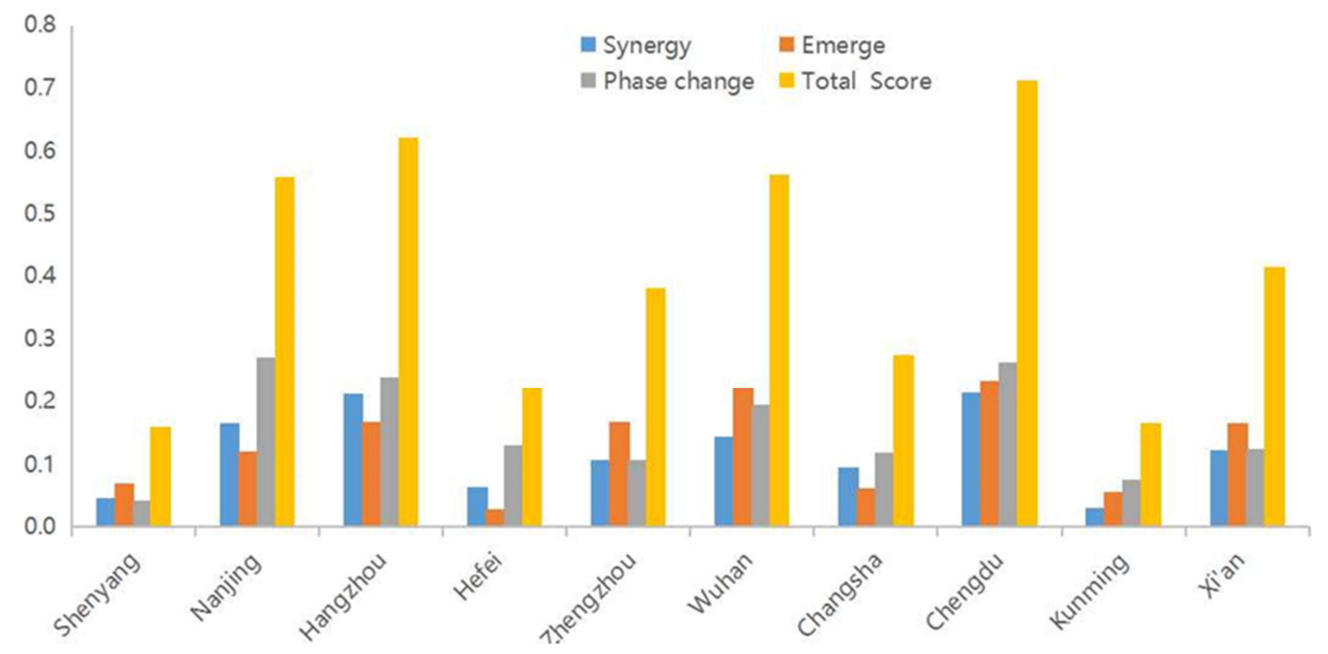

Figure 1. City dimensions and total scores. 
As was shown in Figure 2, in the synergy dimension, Chengdu, Hangzhou and Nanjing ranked in the top three. In the emergence dimension, Chengdu, Wuhan and Hangzhou ranked in the top three. In the phase change dimension, Nanjing, Chengdu and Hangzhou ranked in the top three. It is worth nothing that the cities with the highest overall scores have a more balanced score in all three dimensions. For example, Chengdu ranked first in the synergy and emergence dimensions and second in the phase change dimension, with a clear overall advantage and greater potential. Nanjing ranked first in the phase change dimension because it ranked first in the economy, technological innovation, employment and environment indicators, and ranked second after Hangzhou in technological innovation and Chengdu in employment. For example, Hefei's scores in the emergence dimension and the phase change dimension are several times different. While Kunming and Shenyang's scores in all three dimensions are at a lower level and the difference in score is obvious.

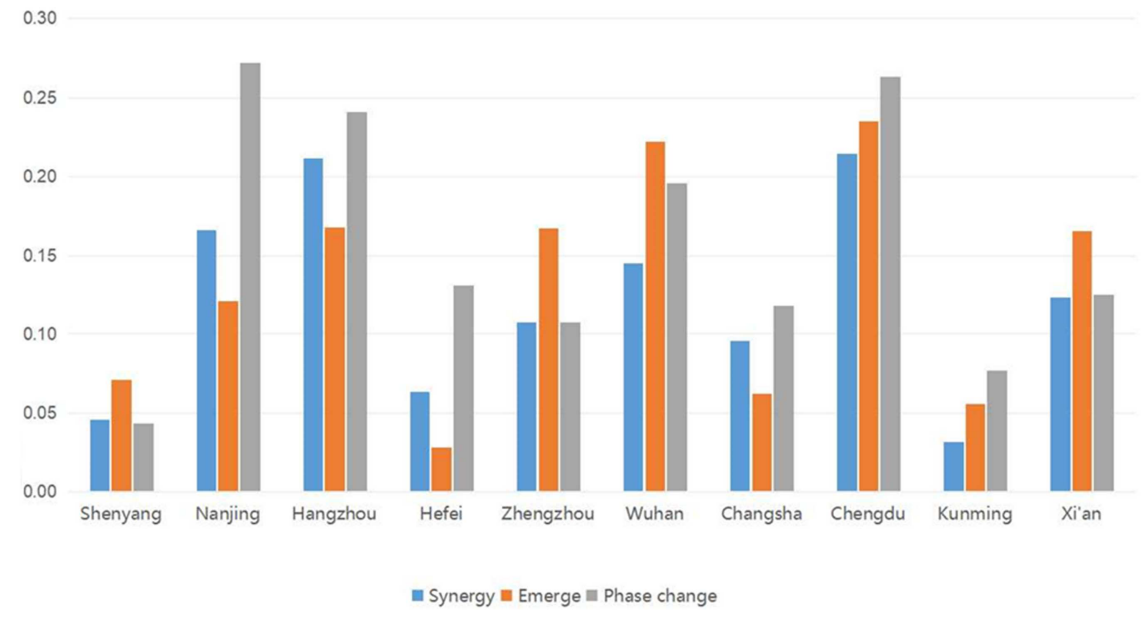

Figure 2. Map of three dimensional scores by city.

The radar chart of secondary indicators for each city is shown in Figure 3. It can be seen that the cities with leading overall scores all have 1-2 indicators with obvious leading advantages, such as employment indicators in Chengdu, education indicators in Wuhan, enterprise indicators in Hangzhou and environmental indicators in Nanjing. The results of the measurement analysis are revealing.

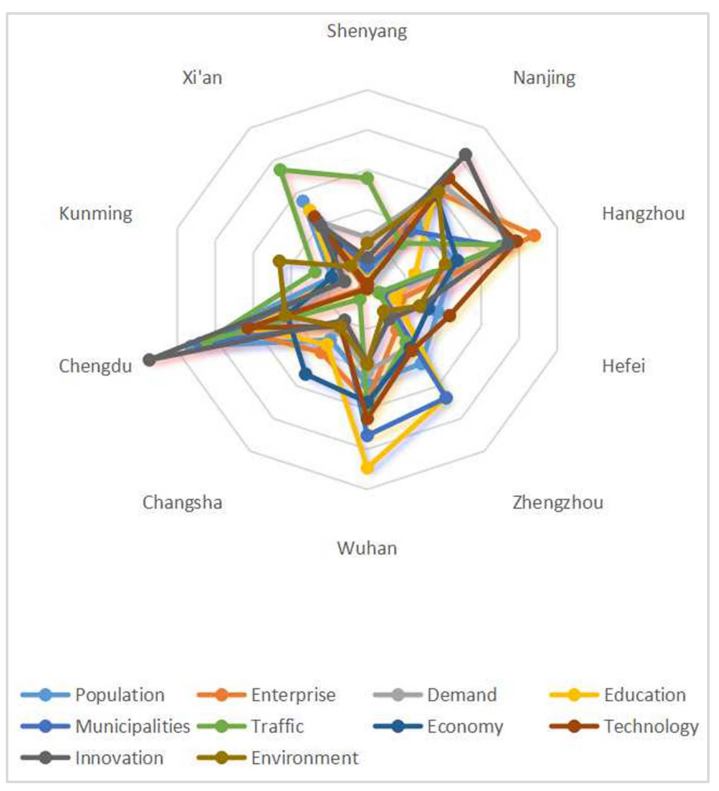

Figure 3. Radar map of secondary indicators by city.

(1) The quality of urban entrepreneurial ecosystems is determined by a multidimensional combination of factors, among which employment, technological innovation, natural environment, municipalities, transportation and education have become key ordinary covariance. And a particularly strong performance on one of the sequential key covariance is a common characteristic of cities with leading overall scores, such as Chengdu and Nanjing.

(2) Employment has always been the basis of livelihoods, both as the main goal to be achieved by entrepreneurial activity and as a core indicator of the quality of urban entrepreneurial ecosystems.

(3) Technological innovation significantly affects the quality of urban entrepreneurial ecosystems, with the leading first-tier cities scoring higher on technological innovation indicators.

(4) Both the hard and soft environments have a positive impact on entrepreneurial activities. In the context of the public's overall emphasis on quality of life, a beautiful environment, municipal cleanliness and convenient transportation have become important considerations for entrepreneurs to choose a place to register with their companies.

(5) The role of knowledge spillover and tacit knowledge dissemination played by education has a greater impact on the entrepreneurial climate of a city, especially the level of teaching and research of faculty and students in higher education institutions, as the main source of entrepreneurs, determines the development potential of a city's entrepreneurial ecosystem. 


\section{Conclusion}

As a typical social system, the complexity of entrepreneurial activity is obvious, and the ultimate goal of its study and measurement is to promote economic development for sustainable livelihood improvement. As an emerging field in entrepreneurship research, the entrepreneurial ecosystem is not only a biological metaphor, but also reveals that the complexity of entrepreneurial activities is rooted in the non-linear interactions among the participating actors. An internal and external study of city-level entrepreneurial ecosystems shows that the relationship between firms and government, as the main participants in entrepreneurial activities, has a significant impact on the type and growth of regional entrepreneurial firms; the natural, cultural and institutional environments of cities determine and sustainably influence regional entrepreneurship.

During the evolution of the entrepreneurial ecosystem, three major characteristics of synergy, emergence and phase change will appear one after another. First, the entrepreneur's personal initiative will greatly influence the establishment of the system's relationship network, thus forming a synergistic evolutionary situation in which all subjects in the entrepreneurial system rely on each other and influence each other; second, each subject forms an objective self-organizing behavior while seeking their own interests, which makes the overall effectiveness of the entrepreneurial ecosystem greater than the simple superposition of the effectiveness of each subject, and this emergent effect is the greatest value of the entrepreneurial ecosystem and the fundamental reason why entrepreneurial activities can drive economic development; finally, through a long period of high-quality development and the establishment of continuous and open interaction with the outside world, the urban entrepreneurial ecosystem will gradually transition from factor-driven to efficiency-driven and finally to innovation-driven, and the transformation and upgrading between these three stages is a process of phase change.

By constructing the Urban Entrepreneurship Ecosystem Index (UEEI) with three dimensions of synergy, emergence and phase change, 10 primary indicators and 40 secondary indicators, this study hopes to integrate many economic and non-economic indicators based on the theory of complexity science, and comprehensively examine the quality of urban entrepreneurial activities from the perspective of complex systems. This study aims to examine the quality of urban entrepreneurial activities from a complex system perspective by integrating many economic and non-economic indicators based on complexity science theory. This study verifies the reasonableness and usefulness of this index system by analyzing 10 quasi-first-tier cities in China. The results show that cities with high quality entrepreneurial ecosystems have balanced performance and high scores in all three dimensions, while cities with low scores have low scores in all dimensions and large differences in scores; among the primary and secondary indicators reflecting the quality of the system, soft environments such as employment, technological innovation and education, and hard environments such as PM2.5, municipalities and transportation are important. These soft and hard environments are key ordinal parameters that determine the overall characteristics of a city's entrepreneurial ecosystem, and particularly good performance on one of the key ordinal parameters is a common characteristic of cities with high overall scores, such as Chengdu, Nanjing and Wuhan.

Creating a sustainable, high-quality urban entrepreneurial ecosystem is not an easy task due to the complexity of the system. For large cities in China, finding their own characteristics and differentiating advantages based on their historical and cultural heritage and economic geography is the key to developing entrepreneurial ecosystems and driving economic development through entrepreneurship. The way to improve the quality of urban entrepreneurial ecosystem is to improve the hardware and software, enhance the efficiency of urban governance, make full use of policy leverage to promote scientific and technological innovation and transformation of technological achievements, encourage high-level technical personnel to engage in entrepreneurial activities, create a positive entrepreneurial culture and social atmosphere, and attract well-known enterprises and entrepreneurs with favorable conditions.

\section{Acknowledgements}

This research is supported by the following projects: Key Project of Hunan Philosophy and Social Science Achievement Evaluation Committee (XSP20ZDI006); General Scientific Research Project of Education Department of Hunan Province, No. 19C0909, no. 20 C0936.

\section{References}

[1] Zoltán J. Ács, László Szerb, Esteban Lafuente, Gábor Márkus. The Global Entrepreneurship Index (2019) [M]. The Global Entrepreneurship and Development Institute, 2019: 58-69.

[2] Stam E. Handbook of research on innovation and entrepreneurship [M]. Cheltenham: Edward Elgar, 2011: 421-438.

[3] Stam Erik, Van de Ven, Andrew. Entrepreneurial Ecosystem Elements. Small Business Economics [J]. 2019, (3): 173-197.

[4] Xiaoqing X., Jingjing H. An Evaluation Analysis of Urban Entrepreneurship Environment Based on PSR Model: Case of Wuhan [J]. China Soft Science, 2017 (02): 172-182.

[5] Rui W. Evaluation of Urban Entrepreneurial Environment in China Based on PSR Model - A Case Study of Four Municipalities [J]. Journal of Industrial Technological Economics, 2018, 37 (06): 92-99.

[6] Hemmert, M., Cross, A. R., Cheng, Y. et al. The distinctiveness and diversity of entrepreneurial ecosystems in China, Japan, and South Korea: an exploratory analysis [J]. Asian Bus Manage. 2019, 18 (5): 211-247.

[7] Audretsch, D. B., Belitski, M. Entrepreneurial ecosystems in cities: establishing the framework conditions [J]. J Technol Transf. 2017, 42 (4): 1030-1051. 
[8] European Commission. The Regional Entrepreneurship and Development Index - Measuring regional entrepreneurship [M], Publications Office of the European Union, 2014: 168-172.

[9] Acs Z, Autio E, Szerb L. National systems of entrepreneurship: Measurement issues and policy implications [J]. Research Policy, 2014, 43 (3), 449-476.

[10] Audretsch, D. B, Link, A. N. Concise guide to entrepreneurship technology and innovation [M]. Chelterham: Edward Elgar, 2015: 321-325.

[11] Estrin S, Korosteleva J, Mickiewicz T. Which institutions encourage entrepreneurial growth aspirations? [J]. Journal of Business Venturing. 2013, 28 (4), 564-580.

[12] Stenholm, P., Acs, Z. J., \& Wuebker, R. Exploring country-level institutional arrangements on the rate and type of entrepreneurial activity $[\mathrm{J}]$. Journal of Business Venturing, 2013, 28 (1): 176-193.

[13] Fritsch, M., \& Storey, D. Entrepreneurship in a regional context-Historical roots and recent developments [J]. Regional Studies, 2014, 48 (5): 939-954.

[14] Bosco, B. et al. Innovative startup creation: the effect of local factors and demographic characteristics of entrepreneurs $[\mathrm{J}]$. International Entrepreneurship and Management Journal. 2019, 25 (12): 1-20.

[15] Lichtenstein, B. The Sage handbook of complexity and management [M], London: Sage, 2011: 471-793.

[16] Lindsay, V. J. The development of international industry clusters: A complexity theory approach [J]. Journal of International Entrepreneurship. 2005, 3 (1): 71-97.

[17] Tan, J. Phase transitions and emergence of entrepreneurship:
The transformation of Chinese SOEs over time [J]. Journal of Business Venturing. 2007, 22 (1): 77-96.

[18] Stam, E. Entrepreneurial ecosystems and regional policy: A sympathetic critique [J]. European Planning Studies. 2015, 23 (9): 1759-1769.

[19] Fuller T, Warren L, Argyle P. Sustaining entrepreneurial business: A complexity perspective on processes that produce emergent practice $[\mathrm{J}]$. International Entrepreneurship and Management Journal. 2008, 4 (1), 1-17.

[20] Swanson, L. A., \& Zhang, D. D. Complexity theory and the social entrepreneurship zone [J]. Emergence: Complexity and Organization. 2011, 13 (3): 39-56.

[21] Jianming G., Zhaogang S. On the Interrelation between Complexity and Non-linearity [J]. Journal of Systemic Dialectics, 2002 (04): 34-37.

[22] Haimeng L., Chuanglin F., Peiji S. Mechanism of oasis urbanization: A theoretical framework based on complexity theory [J]. Geographical Research, 2016, 35 (02): 242-255.

[23] Goldstein, J. A., Hazy, J. K., \& Silberstang, J. Complexity and social entrepreneurship: A fortuitous meeting [J]. Emergence: Complexity and Organization. 2008, 10 (3): 9-24.

[24] Chenglei X., Ding W., Wanchun D. Entrepreneurial Team Collaboration Clusters Complexity and Identify the Key Interface [J]. Science \& Technology Progress and Policy, 2017, 34 (05): 148-155.

[25] Jiacheng N. Research on the mechanism of market segmentation on technology entrepreneurship from the perspective of institutional complexity [D]. University of International Business and Economics, 2020. 